\title{
Effects of ATutor Platform on Learning Outcomes in Agricultural Science among University Students in North-Central, Nigeria
}

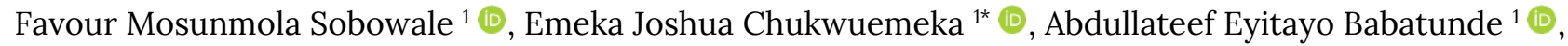 \\ Samaila Dominic ${ }^{1}$ (])
}

${ }^{1}$ Department of Educational Technology Federal University of Technology, Minna, Niger State, NIGERIA *Corresponding Author: emekac.joshua@gmail.com

Citation: Sobowale, F. M., Chukwuemeka, E. J., Babatunde, A. E., \& Dominic, S. (2020). Effects of ATutor Platform on Learning Outcomes in Agricultural Science among University Students in North-Central, Nigeria. European Journal of Interactive Multimedia and Education, 1(1), e02005. https://doi.org/10.30935/ejimed/8362

\begin{abstract}
The study examined the effects of ATutor Platform on learning outcomes in Agricultural Science among university students in North-Central, Nigeria. The researcher used quasi-experimental design (pretest, posttests, nonrandomized, non-equivalent experimental and control groups design). The population of the study was 4,562 students. The sample size for the study comprised 237 students from two Universities in North-Central, Nigeria drawn from the population. The research instrument was developed by the researchers and validated by two experts, from the Department of Educational Technology, Federal University of Technology, Minna. To determine the reliability of Agricultural Science Achievement Test (ASAT), Spearman Brown Coefficient was used to analyse the data that was collected from ASAT administered to the students using SPSS version 20, a reliability coefficient of 0.81 was obtained which is above the bench mark of 0.70 . This shows that the instrument was reliable. To determine the reliability of Agricultural Science Satisfaction Questionnaire (ASSQ), Cronbach Alpha was used to analyse the data collected and a reliability coefficient of 0.85 was obtained, which shows that the instrument was reliable. To determine the reliability coefficient of Agricultural Science Interest Inventory (ASII), Cronbach Alpha was also used and when analysed, a reliability coefficient of 0.75 was obtained which showed that the instrument is suitable for the categories of students in this study. Three research questions guided the study while the three hypotheses formulated were tested at 0.05 level of significance. Frequency counts, mean $(\mathrm{X})$ and standard deviation (SD) were employed to answer the research questions while t-test was used to test the hypotheses. Findings showed significant difference between the students taught using ATutor Platform and those taught using lecture method. It was concluded that ATutor Platform should be employed to teach Agricultural Science. It was also recommended that ATutor Platform be used in teaching and learning process among others.
\end{abstract}

Keywords: agricultural science, learning outcomes, ATutor, learning content management system

Received: 22 May $2020 \bullet$ Accepted: 13 Jun. 2020

\section{INTRODUCTION}

Science and technology have in no small way impacted every facet of human endeavours. The advent of science and technology has continued to create positive impacts on different sectors especially in education where it has played a major role in sustaining teaching processes that can enhance learning. This is evident in the learning outcome of students at all level of education which includes primary, secondary and tertiary institutions. It has specifically affected teaching and learning processes in tertiary institutions in support of the National Policy on Education (NPE) (Ogbuzuru, 2011). Information and Communication Technology (ICT) is regarded as a strong tool for sustainable development empowering people for global competitiveness. This culminated in the development and propagation of ICT policy in Nigeria and for the Nigerian University system. To this end, the National Universities Commission (NUC) in 1994 initiated efforts to put in place a National ICT network with full internet connectivity in Nigerian universities. The impact of ICT on Nigerian universities teaching and learning processes are enormous (Oyekunle \& Majebi, 2013).

For a more proactive and valuable teaching-learning process, elearning environments has been introduced which has increased the need for content and learning management (Sen, 2015). Several content and learning management platforms like Edmodo, Massive Open Online Courses (MOOC) platforms (EdX and Coursera) and cloud file hosting services such as Google Drive and DropBox have become very popular in the past. In the same vein, the number of educational mobile platforms applications such as MOODLE, WizIQ, ATutor, WhatsApp, Facebooks, Adobe Connect, Blackboard, WebCT among others have being on the increase and most of these platforms are widely used for teaching and learning processes especially at higher levels of education. It was observed by Stantchev et al., (2014) that using LMS platform has

( 2020 by the authors; licensee EJIMED by Bastas, UK. This article is an open access article distributed under the terms and conditions of the Creative Commons Attribution License (http://creativecommons.org/licenses/by/4.0/). 
provided students and teachers better approach to teaching and learning processes which is better managed when compared with lecture method.

ATutor is an open source, online learning environment used to develop web-based courses, author e-learning content, and present instructional materials on the internet. ATutor is an acronym coined from the place of development. It was developed at Adaptive King Technology Resource Centre University of Toronto. Adaptive Technology University of Toronto was shortened to ATutor. It can be used to author and archive learning content with a large collection of modular tools that can be combined in different ways to adapt the system to various theoretical approaches for teaching and learning (Gay, 2012). ATutor is unique for providing versatile spaces open for collaboration among students with support from the tutors especially as the students chat online. Sulisworo (2012) observed that when ATutor is used for assignments, it helps to foster collaborative and group interaction, it can be a rewarding learning tool that develops learning skills such as problem solving, collaboration/idea sharing and employability skills such as communication, creativity, leadership and technology proficiency especially in tertiary institutions.

Tertiary institution in Nigeria includes Universities, Polytechnics, Monotechnics and Colleges of education (Amaghionyeodiwe \& Osinubi 2007). Agricultural science is one of the courses offered at tertiary institutions with different options like Animal Production, Crop Production, Agricultural Economic and Extension depending on the nature of the university. The need to address agricultural training at the university level is in this way two fold; firstly by managing student's enthusiasm and interest from encounters in primary school, secondary school and secondly by aiding students to proceed with that mind-set to tertiary level, possibly through technological and innovative lesson presentations so as to comprehend the potentials that agriculture offers.

Learning outcomes in this study however include: academic achievement and interest. Achievement is really the outcome or result of student in subjects or courses at a given time. It can also be defined as outcome of a conquest, what is attained, what is accomplished, being successful and to gain recognition (Norris, Sporre \& Svendsen, 2013). Sadanand and Kumbhar (2012) also found out that most students have a positive attitude and interest towards ATutor on a particular topic, thereby enhancing better outcome in achievement, interest and satisfaction. Interest is an excitement or feeling accompanied by special attention to do something (Gimba, 2013). Mangal (2010) observed that appropriate learning environment and methods, functional teaching material and a motivating teacher have positive effect on students' interest in learning and meaningful learning experiences. In the same vein satisfaction can be defined as fulfilling expectations, needs, wishes or pleasure derived from an event. It can then be seen as level of fulfillment from teaching and learning process for better academic achievement. Lo (2010) emphasized that strong satisfaction activates students' systematic intellectual capabilities and ability to learn effectively.

In a study also carried out by Sanserm (2010) to examine students' and instructors' perceptions of using ATutor as the learning content management system (LCMS) in e-learning courses at a distance university in Thailand. The population was composed of all 222 graduate students (census) and 10 instructors from an agricultural college at a major university in Thailand. Survey and focus group interview were used to collect data. Descriptive statistics and the
Pearson Product Moment Correlation Coefficient were used to analyze data provided by respondents. It was found out that comfort of using computer and ATutor, time spent online, place and frequency accessing ATutor, internet access and connection had significant and positive correlation to students' perception of using ATutor while E-mail student, chat, forum, and group forum participated, ATutor satisfaction, online teaching experience, role in teaching, support from the university, and workshop attended had significant positive correlation to instructors' perception of using ATutor. The overall mean scores of students' perception of the usefulness, ease of use, interaction and communication, e-learning and pedagogical design, online learning, and self-directed learning ranged from 6.84 to 7.49 out of 10 , and standard deviations ranged from 1.47 to 1.95 . The overall mean scores of Instructors' perception of the usefulness, ease of use, interaction and communication, and teaching online by using ATutor ranged from 5.70 to 7.40 out of 10 , and standard deviations ranged from 1.35 to 2.00 . All six student perception variables and all four instructor perception variables had positive and significant correlation. The most important feature for students was content navigation and for instructors was announcement. Both students and instructors reported that poll was the least important feature. Most students and instructors indicated that no features should be added or removed from ATutor. ATutor supports self-directed learning because it enhances students' ability to set an appropriate pace for learning and get assistance from various resources thereby enhancing their academic achievement. In this context, ATutor detracted from self-directed learning due to course schedule and technological problems. This differs from the present study in the sense that, the present study is investigating the effect of ATutor on satisfaction and interest of undergraduates in Agricultural science and the effect of achievement.

A study was carried out by Wathanti and Chaithongsri (2015) using Electronic Learning Management system (ATutor) in developing good outcome for learning and achievement and to also determine the level of satisfaction of the students. The students undergoing Business Administration Programme in Computer Information System were used for the study at Rajamangala University of Technology Isan Sakon Nakhon Campus in India. It was found out after the data analysis that the scores of the students was higher after learning than before learning which represented better achievement. It was also found out that the satisfaction levels of respondents were higher after learning than before learning. In a study also carried out by Firat (2016), the effects of undergraduate students' LMS learning behaviors on their academic achievements was investigated. Learning analytics was used for 14 weeks on the 71 undergraduate students that participated in the study and after the analysis, it was revealed that the students used LMSs as a support to face-to-face education more intensively on course days (at the beginning of the related lessons and at nights on course days) and that they activated the content elements the most. Lastly, almost all the students agreed that LMSs helped increase their academic achievement only when LMSs included such features as effectiveness, interaction, reinforcement, attractive design, social media support, and accessibility. This study has similarities with the present study in the sense that undergraduates were used for the study but differences lies in the location and subject area.

It is on the above assertion that the theoretical framework for this study hedges on socio-constructivist theory which allows the students take responsibilities for individualistic approach of learning. In selfregulated learning, students are motivated, independent, and become 
meta-cognitively active learners in their own learning. Therefore, this study attempts to investigate the effectiveness of ATutor approach on learning outcomes in Agricultural Science among undergraduates in North-Central, Nigeria.

\section{STATEMENT OF THE RESEARCH PROBLEM}

The poor performance of students in Agricultural Science especially in Anatomy and Physiology in faculties of Agricultural Science has been a source of concern to lecturers and the school management in Nigerian universities. It was observed by Bada et al. (2012) that many problems especially abstract nature of anatomy and physiology, lack of interest, inadequate innovative strategies and failure to integrate technology in instructional process among others added to the poor academic performance of students. It was also observed that most of the science lecturers do not have access to action-based-learning and accordingly the system for instruction has been the lecture method and the mode of course management has been note taking in lecture halls. In other words, lecturer-centered approach dominates the system (Akpoghol et al., 2016). However, to make learning to be student-centered, ATutor as online learning platforms have been observed to enable educators to design online courses in which the students can access anytime like a virtual classroom (Chukwuemeka et al., 2015). Students may be intellectually and physically capable to learn but may never learn until their interest is aroused through an attractive approach of teaching When the student's interest is aroused using a good teaching approach, sustaining his attention may be guaranteed and could equally promote effective learning (Ben, 2013). It was noted by Naaj, Nachouki and Ankit (2012) that the satisfaction of learners under virtual learning environment is the baseline requirement for a successful implementation of planned lessons that could improve students achievement. Sadanand and Kumbhar (2012) found out that most students have interest towards online learning platforms. It was noted by some of the studies cited on the effects of ATutor platforms to the best of the researcher's knowledge were not carried out on Agricultura Science and also not in North-Central, Nigeria which is one of the gaps that is needed to be filled in this study. Gender issues are also yet inconclusive, gender implication especially as it affects achievement, interest and satisfaction in Agricultural Science needs more verification. Hence, the need for this study to investigate effects of ATutor Platforms on learning outcomes of undergraduate Agricultural Science students in North-Central, Nigeria.

\section{AIM AND OBJECTIVES OF THE STUDY}

The aim of this study is to determine the effects of ATutor Platform on learning outcomes in Agricultural Science among university students in North-Central, Nigeria. The objectives guiding this study are to:

1. examine the effectiveness of using ATutor Platform and lecture method on academic achievement of undergraduate Agricultural Science students in North-Central, Nigeria.

2. determine the effect of ATutor Platform and lecture method on the interest of undergraduate students towards Agricultural Science in North-Central, Nigeria.
3. examine the level of satisfaction among undergraduate students after using ATutor and Lecture Method in learning of Agricultural Science in North-Central.

\section{RESEARCH QUESTIONS}

The following questions were raised in order to achieve the above stated objectives.

1. How effective is the use of ATutor Learning Platform and lecture method on academic achievement of undergraduate Agricultural Science students in North-Central, Nigeria?

2. What is the influence of ATutor Learning Platform and lecture method on the interest of undergraduate students towards Agricultural Science in North-Central, Nigeria?

3. What is the level of satisfaction among undergraduate students after using ATutor Learning Platform and lecture method in learning Agricultural Science in North-Central, Nigeria?

\section{RESEARCH HYPOTHESES}

The following null hypotheses were formulated and tested at 0.05 alpha levels.

HO1: There is no significant difference in the mean achievement scores of undergraduate students taught Agricultural Science using ATutor Learning Platform and those taught using lecture method in North-Central, Nigeria

$\mathbf{H O}_{2}$ : There is no significant difference in the mean interest scores of undergraduate students taught Agricultural Science using ATutor Learning Platform and those taught using lecture method in North-Central, Nigeria.

HO3: There is no significant difference in the satisfaction of undergraduate students after learning Agricultural Science through ATutor Learning Platform and lecture method in North-Central, Nigeria.

\section{RESEARCH METHODOLOGY}

The study adopted a quasi-experimental research design. The population of this study comprised of 4,562 Agricultural Science students in all the Universities in North-Central. The sample size for this study was 222 students from the two universities selected for this study. A multistage sampling technique was adopted in this study. Two universities were randomly selected from the seven conventional universities in North-Central that will be used for this study. The topic taught was in the curriculum of 200 level students which inform the choice of the level.

There were four instruments developed by the researcher for this study. Treatment Instruments: ATutor Platform (AP); Test Instruments: Agricultural Science Achievement Test (ASAT); Satisfaction Questionnaire: Agricultural Science Satisfaction Questionnaire (ASSQ); Interest Inventory: Agricultural Science Interest Inventory (ASII).

ATutor Platform was validated by Educational Technology experts and Computer Science experts and two Agricultural Science Lecturers from the Department of Animal Production, School of Agriculture and 
Table 1. Mean and standard deviation of pretest and posttest Mean Achievement scores of students taught Agricultural Science with ATutor Platform

\begin{tabular}{|c|c|c|c|c|c|c|}
\hline \multirow{2}{*}{ Group } & \multicolumn{3}{|c|}{ Pretest } & \multicolumn{3}{|c|}{ Post test } \\
\hline & $\mathbf{N}$ & Mean $(\bar{X})$ & SD & Mean $(\bar{X})$ & SD & Mean Gain \\
\hline Experimental (ATutor Approach) & 120 & 33.46 & 8.01 & 64.17 & 7.97 & 30.71 \\
\hline Control (Lecture Method) & 102 & 36.61 & 8.39 & 60.43 & 11.26 & 23.82 \\
\hline
\end{tabular}

Table 2. Mean and standard deviation of pretest and posttest Mean Interest scores of students taught Agricultural Science with ATutor Platform

\begin{tabular}{ccccccc}
\hline \multirow{2}{*}{ Group } & \multicolumn{4}{c}{ Pretest } & \multicolumn{3}{c}{ Posttest } \\
\cline { 2 - 7 } & $\mathbf{N}$ & Mean $(\bar{X})$ & SD & Mean $(\bar{X})$ & SD & Mean Gain \\
\hline Experimental (ATutor Approach) & 120 & 54.07 & 6.00 & 60.61 & 6.02 & 6.54 \\
\hline Control (Lecture Method) & 102 & 56.45 & 5.89 & 56.66 & 5.98 & 0.21 \\
\hline
\end{tabular}

Table 3. Mean and standard deviation of pretest and posttest Mean Satisfaction scores of students taught Agricultural Science with ATutor Platform

\begin{tabular}{ccccccc}
\hline \multirow{2}{*}{ Group } & \multicolumn{3}{c}{ Pretest } & \multicolumn{3}{c}{ Posttest } \\
\cline { 2 - 7 } & $\mathbf{N}$ & Mean $(\bar{X})$ & SD & Mean $(\bar{X})$ & SD & Mean Gain \\
\hline Experimental (ATutor Approach) & 120 & 60.70 & 8.34 & 57.88 & 7.83 & -2.83 \\
\hline Control (Lecture Method) & 102 & 60.70 & 8.34 & 61.28 & 8.26 & 0.58 \\
\hline
\end{tabular}

Agricultural Technology, Federal University of Technology, Minna in order to determine the appropriateness of the learning platform as well as the suitability for the level of the students. The experts ascertained that the instrument was technically sufficient to impact knowledge on Anatomy and Physiology of Farm Animals. The Agricultural Science Achievement Test was also validated by two lecturers from the Department of Animal Production, School of Agriculture and Agricultural Technology, Federal University of Technology, Minna. The Interest Inventory was validated by a lecturer that specializes in Guidance and Counselling in the department of Science Education, Federal University of Technology, Minna. The instrument ASSQ was validated by a lecturer from the Department of Educational Technology that have background in Guidance and Counselling to determine the appropriateness of the instrument.

At the commencement of the study, adequate permissions were obtained by the researchers from the school management through the departmental heads to have contact with the students that were used for this study. Each of the two randomly selected schools were assigned to experimental and control groups. The students were trained on the procedure for carrying out the experiment in one week. During the third week before the commencement of the experiment; the ASAT, ASII and ASSQ was administered on the students in all the selected schools as pretest. The main objective of administering the pretest was to ascertain the academic equivalent of the students in Agricultural Science before the commencement of the experiment. Treatment was followed thereafter and lasted for six weeks based on universities academic calendar and scheme of work. The study lasted for Fourteen weeks.

Research questions one to three were answered using descriptive statistics of mean and standard deviation. t-test statistics was used to analyze the data collected for the pretest. 0.05 level of significance was adopted for all analyses as the criterion for significance which was used to determine if the hypotheses was rejected or accepted. SPSS statistic version 20 was used for the analyses.

\section{RESULTS}

Research Question One: How effective is the use of ATutor Platform on academic achievement of undergraduate Agricultural Science students in North-Central, Nigeria?
Table 1 shows that the students who were taught Agricultural Science using ATutor had mean achievement score of 64.17 with a standard deviation of 7.97 at the post-test against their pre-test mean achievement score of 33.6 and standard deviation of 8.01 , while those who were taught using lecture method had mean score of 60.43 with a standard deviation of 11.26 , while the pretest mean score was 36.61 with standard deviation 8.39 . There was a Mean $(\bar{X})$ gain scores of 30.71 and 23.82 for experimental and control groups. This shows that the students who were exposed to ATutor had higher mean achievement score than those taught using lecture method.

Research Question Two: What is the effect of ATutor Platform on the interest of undergraduate students towards Agricultural Science in North-Central, Nigeria?

Table 2 shows that the students who were taught Agricultural Science using ATutor had mean interest scores of 60.61 with a standard deviation of 6.02 at the post-test against their pre-test mean interest score of 54.07 and standard deviation of 6.00 , while those who were taught using lecture method had mean score of 56.66 with a standard deviation of 5.98, while the pretest mean score was 56.45 with standard deviation 5.89. There were mean gain scores of 6.54 and 0.21 for the two groups. This shows that the students who were exposed to ATutor had higher mean interest score than those taught using lecture method.

Research Question Three: What is the level of satisfaction among undergraduate students after using ATutor Platform in learning Agricultural Science in North-Central, Nigeria?

Table 3 shows that the students who were taught Agricultural Science using ATutor had mean satisfaction scores of 57.88 with a standard deviation of 7.83 at the post-test against their pre-test mean satisfaction score of 60.70 and standard deviation of 8.34 , while those who were taught using lecture method had mean score of 61.28 with a standard deviation of 8.26 , while the pretest mean score was 60.70 with standard deviation 8.34. There were mean loss scores of -2.83 for students taught ATutor while 0.58 was mean gain obtained for the students taught lecture method. This shows that the students who were exposed to Lecture Method had higher mean satisfaction scores than those taught with ATutor Platform. 
Table 4. Summary of t-test Analysis of Achievement Scores of undergraduate students taught Agricultural Science using ATutor Platform

\begin{tabular}{|c|c|c|c|c|c|c|}
\hline Group & $\mathbf{N}$ & df & $\overline{\bar{X}}$ & SD & t-value & P-value \\
\hline Experimental (ATutor Approach) & 120 & \multirow{2}{*}{220} & 64.17 & 7.97 & \multirow{2}{*}{0.001} & \multirow{2}{*}{0.004} \\
\hline Control (Lecture Method) & 102 & & 60.43 & 11.25 & & \\
\hline
\end{tabular}

Significance at 0.05

Table 5. Summary of t-test Analysis of Interest Level of undergraduate students taught Agricultural Science using ATutor Platform

\begin{tabular}{|c|c|c|c|c|c|c|}
\hline Group & $\mathbf{N}$ & df & $\overline{\boldsymbol{X}}$ & SD & t-value & P-value \\
\hline Experimental (ATUTOR Approach) & 120 & \multirow{2}{*}{220} & 60.61 & 6.02 & \multirow{2}{*}{0.918} & \multirow{2}{*}{0.000} \\
\hline Control (Lecture Method) & 102 & & 56.66 & 5.98 & & \\
\hline
\end{tabular}

Significance at 0.05

Table 6. Summary of t-test Analysis of Level of Satisfaction of undergraduate students taught Agricultural Science Nigeria using ATutor Platform

\begin{tabular}{|c|c|c|c|c|c|c|}
\hline Group & $\mathbf{N}$ & df & $\overline{\bar{X}}$ & SD & t-value & P-value \\
\hline Experimental (ATutor Approach) & 120 & \multirow{2}{*}{220} & 57.88 & 7.83 & \multirow{2}{*}{0.971} & \multirow{2}{*}{0.002} \\
\hline Control (Lecture Method) & 102 & & 61.28 & 8.26 & & \\
\hline
\end{tabular}

Significance at 0.05

\section{Hypotheses Testing}

HO1: There is no significant difference in the mean achievement scores of undergraduate students taught Agricultural Science in NorthCentral, Nigeria using ATutor Platform.

Table 4 shows the $\mathrm{t}$-value was 0.001 , the $\mathrm{P}$-value was 0.004 , which is $\mathrm{P}<0.05$. This means it was significant as such hypothesis one was rejected. The mean achievement score of students taught Agricultural Science using ATutor Platform was 64.17 with standard deviation of 7.97 , while the mean score of students taught lecture method was 60.43 with standard deviation of 11.25. This implies that ATutor Platform enhanced academic achievement better than lecture method with a significant difference. From the mean score, it is obvious that the students learnt better with ATutor Platform.

$\mathbf{H O}_{2}$ : There is no significant difference in the mean interest scores of undergraduate students taught Agricultural Science in NorthCentral, Nigeria using ATutor Platform

Table 5 shows the $\mathrm{t}$-value was 0.918 , the $\mathrm{P}$-value was 0.000 which is $\mathrm{P}<0.05$. This means it was significant as such hypothesis two was rejected. The mean interest scores of students taught Agricultural Science using ATutor Platform was 60.61 with standard deviation of 6.02, while the mean score of students taught lecture method was 56.66 with standard deviation of 5.98. This implies that ATutor Platform increased interest better than lecture method with a significant difference. From the mean score, it is obvious that the students have better interest in Agricultural Science when ATutor Platform is used for teaching compared to when lecture method is used.

$\mathbf{H O}_{3}$ : There is no significant difference in the level of satisfaction of undergraduate students after learning Agricultural Science in NorthCentral, Nigeria through ATutor Platform

Table 6 shows the $\mathrm{t}$-value was 0.971 , the $\mathrm{P}$-value was 0.002 which is $P>0.05$. This means it was significant as such hypothesis three was rejected. The mean satisfaction scores of students taught Agricultural Science using ATutor Platform was 57.88 with standard deviation of 7.83 , while the mean score of students taught lecture method was 61.28 with standard deviation of 8.26 . This implies that lecture method gave students higher satisfaction level compared to ATutor platform. From the mean score, it is obvious that there is difference in their levels of satisfaction when taught Agricultural Science with both ATutor Platform and lecture method.

\section{DISCUSSION OF FINDINGS}

Finding showed that ATutor Platform enhanced academic achievement better than lecture method with a significant difference. In the same vein, it agrees with the finding of Sanserm (2010) who examined students' and instructors' perceptions of using ATutor as the learning content management system (LCMS) in e-learning courses at a distance university in Thailand and observed that ATutor supports self-directed learning because it enhances students ability to set an appropriate pace for learning and get assistance from various resources, thereby enhancing their academic achievement. In this context, ATutor detracted from self-directed learning due to course schedule and technological problems. This differs from the present study in the sense that, the present study is investigating the effect of ATutor on satisfaction and interest of undergraduates in Agricultural science and the effect of achievement. In a related development, the finding of Firat (2016) corroborates this finding, it was revealed that satisfaction was high in the instructor-student interaction and environment design subdimensions, while it was moderate in the course content and teaching process, materials used and communication tools, and attitude towards e-learning sub-dimensions. When interaction and communication tools such as a virtual classroom, forum, chat, e-mail, web pages, animation, video, graphics and images as content tools, and questionnaire as assessment tool were used there was a difference in student satisfaction, and satisfaction was higher in these courses. Student satisfaction was high when the number of materials used in courses was higher, that is, as the number of materials increased, so did the satisfaction level.

Finding revealed that ATutor platform increased interest better than lecture method with a significant difference. This was supported by Sulisworo (2012) who observed that when ATutor is used for assignments, it helps to foster collaborative and group interaction, it can be a rewarding learning tool that develops learning skills such as problem solving, collaboration and idea sharing and employability skills such as communication, creativity, leadership and technology proficiency

Finding revealed that lecture method gave students higher level of satisfaction compared to ATutor when taught Agricultural Science. This finding disagrees with Wathanti and Chaithongsri (2015) who observed that Electronic Learning Management system (ATutor) 
developed good outcome in achievement and enhanced satisfaction level of the students. It was also found out that the satisfaction levels of respondents were higher after learning than before learning.

\section{CONCLUSION}

Based on the findings from this study, it can be concluded that ATutor Platform enhanced undergraduate students' academic achievement in Agricultural Science in North-Central, Nigeria especially in the institution used for this study. It could be as a result of the flexibility that the platform offers, where resources can be easily shared among students and learning facilitators. Also, the interest level of the undergraduate students was increased after ATutor Platform was used in teaching Anatomy and Physiology of Farm Animals in Agricultural Science.

\section{RECOMMENDATIONS}

1. It is recommended that ATutor Platform be incorporated in higher institutions of learning to enhance better academic performance.

2. Also, the management boards in the various higher institutions in Nigeria should help in making provisions for funds to help the incorporation of Learning Management System in the various institutions.

\section{REFERENCES}

Akpoghol, T. V., Ezeudu, F. O., Adzape, J. N., \& Otor, E. E. (2016). Relative Effect of Lecture Method Supplemented with Music and Computer Animation on Senior Secondary School Students' Retention in Electrochemistry. Journal of Education and Practice, 7(4), 87-95. https://doi.org/10.13140/rg.2.1.3445.8003

Amaghionyeodiwe, L. A., \& Osinubi, T. S. (2007). Do Higher Levels of Schooling Lead to Higher Returns to Education in Nigeria? Applied Econometrics and International Development, 7(1), 157-164. https://EconPapers.repec.org/RePEc:eaa:aeinde:v:7:y:2007:i:1_14

Bada, T. A. A., Adekomi, B., \& Ojo, O. A. (2012). Effects of animated agricultural science instructional package on attitude and performance of Junior secondary school students in South West Area, Nigeria. Mediterranean Journal of Social Sciences, 3(1), 425-435. https://doi.org/10.5901/mjss.2012.03.01.425

Ben, J. F. (2013). Philosophy of education. Lagos: Akinwumi Printing Press.

Chukwuemeka, E. J., Edori, P., \& Bakare, O. (2015). Graduate students opinions on learning management systems: the Moodle LMS-a Case Study of EMU. The International Journal of Science and Technoledge, 3(7), 163-170. Retrieved from http://www.theijst.com /wp-content/uploads/2015/08/22.-ST1507-059.pdf

Firat, M. (2016). Determining the effects of LMS learning behaviors on academic achievement in a learning analytic perspective. Journal of Information Technology Education: Research, 15, 75-87. https://doi.org/10.28945/3405
Gay, G. (2012). ATutor LMS: A case study. Open source option for education. London: Spence Ltd.

Gimba, R. W. (2013). Effect of computer-assisted instructional strategy on achievement, retention and interest in set theory among senior secondary school students in Niger State (Unpublished Ph.D. Thesis). University of Nigeria Nsukka, Nsukka.

Lo, C. C. (2010). How student satisfaction factors affect perceived learning. Journal of the Scholarship of Teaching and Learning, 10(1), 4754. https://doi.org/10.12691/education-3-12-7

Mangal, S. K. (2010). Essentials of Educational Psychology (pp. 351-359). New Delhi: PHI Learning Private Limited.

Naaj, M. A., Nachouki, M. \& Ajman, A. A. (2012).Evaluating student satisfaction with blended learning in a gender segregated environment. Journal of Information Technology Education, University of Science and Technology, Ajman, United Arab Emirates, 11(1), 20-31. https://doi.org/10.28945/1692

Norris, L., Sporre, L., \& Svendsen, D. (2013). The use of Moodle at CASS Business School: A student perspective. 2nd Moodle Research Conference, Sousse, Tunisia. Retrieved from www.research.moodle. net

Ogbuzuru, R. (2011). Strategies for improving skill acquisition of building technology students in technical colleges in Ebonyi State (Masters Thesis). University of Nigeria.

Oyekunle, R. A., \& Majebi, O. V. (2013). An evaluation of the websites of Nigerian Universities. International Journal of Information Processing and Communication, 1(1), 60-72. https://doi.org/10.11648 /j.ijiis.20150406.11

Sadanand, Y., \& Kumbhar, R. (2012). E-learning experience using open source software: MOODLE. Journal of Library \& Information Technology, 32(5), 409-416. https://doi.org/10.14429/djlit.32.5. 2650

Sanserm, S. K. (2010). Student and instructor perceptions of using ATutor as the learning content management system for learning at a distance in Thailand (Ph.D. thesis), Oklahoma State University. Retrieved on August 8, 2018 from https://www.learntechlib.org/p/126905/

Sen, D. (2015). Positive and negative of using a system like Moodle. International Conference on Computer Science and Information Systems (ICCSIS-15) April 24-25, 2015 Pattaya (Thailand) https://doi.org/10.15242/IAE.IAE041501234

Stantchev, V., Colomo-Palacios, R., Soto-Acosta, P., \& Misra, S. (2014). Learning management systems and cloud file hosting services: A study on students' acceptance. Computers in Human Behavior, 31, 612619. https://doi.org/10.1016/j.chb.2013.07.002

Sulisworo, D. (2012). Designing the Online Collaborative Learning Using the Wikispaces. International Journal of Educational Technology, 7(1), 54-63. https://doi.org/10.3991/ijet.v7i1.1863

Wathanti, S., \& Chaithongsri, A. (2015). The Use of Electronic Learning Management System to Enhance Learning and Achievement Case Study: Course Analysis and Design Students of the Program Department of Computer Information Systems. The Twelfth International Conference on eLearning for Knowledge-Based Society, 11-12 December 2015, Thailand. Retrieved from http://www.ijcim.th.org/SpecialEditions/v23nSP2/02_60A_The_ Use.pdf 